\title{
RISIKO POSTUR KERJA TERHADAP KELUHAN SUBYEKTIF NYERI LEHER PADA PEKERJA INDUSTRI KERAJINAN KULIT
}

\author{
Ekawati Wasis Wijayati \\ Prodi Kesehatan Masyarakat, Fakultas Ilmu Kesehatan \\ Institut Ilmu Kesehatan Bhakti Wiyata Kediri \\ Email: ekawati.wasis@gmail.com
}

\begin{abstract}
Musculoskeletal complaints are generally felt a lot because of the habits done during work. Body posture when working improperly and maintained in a relatively long time can lead to musculoskeletal complaints. Working in a sitting position for a relatively long period of time with a bent over body position can be a risk factor for complaints of neck pain or low back pain. The purpose of this research is to analyze the relationship between length of maintaining work posture to with subjective complaints of neck pain in leather craft industry workers in Selosari. The research design was an observational analytic study with a cross sectional approach. The sampling technique in this research is proportional random sampling with a sample of 42 respondents from the leather craft industry workers in Selosari. The results of statistical analysis with the Chi Square test showed that $p=0.006$ ( $p<0.05)$, which means there is a correlation between the length of maintaining work posture to subjective complaints of neck pain in leather craft industry workers in Selosari. It should be noted that prolonged retention of neck posture which is too bend when working continuously for long periods of time will increase the risk of neck pain complaints. So it is necessary to improve the posture of the body when working, especially the neck or movement or changes in posture, especially the neck if to feel achy or stiff in the neck.
\end{abstract}

Keywords: leather craft, musculoskeletal complaints, neck pain, work posture

\section{PENDAHULUAN}

Pada umumnya, orang yang merasakan keluhan muskuloskeletal berawal dari kebiasaan yang dilakukan selama bekerja. Jika postur kerja yang dilakukan tidak tepat dan dipertahankan dalam durasi yang relatif lama, maka dapat memicu timbulnya keluhan muskuloskeletal (Alfara et al, 2017). Postur kerja tidak alamiah merupakan sikap atau postur tubuh saat bekerja yang menyebabkan bagian-bagian tubuh menjauhi posisi alamiahnya, seperti posisi punggung yang terlalu membungkuk, posisi leher yang terlalu mendongak atau menunduk, serta posisi lain yang tidak sesuai dengan posisi alamiahnya (Tarwaka, 2015).

Pekerja pada industri kerajinan kulit di Selosari yang memproduksi sepatu dan sandal merupakan pekerja yang bekerja dengan posisi duduk dalam jangka waktu yang relatif lama dengan posisi tubuh cenderung membungkuk dan menunduk. Postur kerja yang demikian dapat menjadi faktor risiko timbulnya keluhan nyeri leher maupun nyeri punggung. Penelitian Safitri, et al (2017) pada pekerja pabrik sepatu dan 
sandal kulit Kurnia di kota Semarang menunjukkan hasil bahwa sebagian besar informan mengalami keluhan neck pain dimana keluhan tersebut muncul setelah bekerja, terutama saat akan tidur.

Hasil wawancara saat survei pendahuluan yang dilakukan terhadap 4 pekerja, semuanya menyatakan sering merasakan keluhan sakit atau nyeri pada bagian leher setelah bekerja, bahkan 2 orang diantaranya menyatakan terkadang juga merasakan keluhan nyeri pada bagian punggung bawah atau pinggang. Penelitian yang dilakukan Ginting dan Malik (2016) pada pekerja di UKM sepatu kulit menunjukkan bahwa keluhan nyeri yang paling sering muncul pada rata-rata operator adalah keluhan pada bagian pinggang $(8,91 \%)$ dan bagian leher (7,92\%). Observasi terhadap pekerja selama melakukan pekerjaan menunjukkan bahwa selama melakukan proses pembuatan sepatu dan sandal, postur tubuh pekerja tidak alamiah yaitu punggung membungkuk dan leher menunduk. Berdasarkan hal tersebut, maka dapat dirumuskan permasalahan dalam penelitian ini adalah "Apakah ada hubungan antara lama mempertahankan postur kerja dengan keluhan subyektif nyeri leher pada pekerja industri kerajinan kulit di Selosari?". Penelitian ini bertujuan untuk mengetahui lama mempertahankan postur kerja dan keluhan subyektif nyeri leher yang dirasakan responden serta menganalisis hubungan antara lama mempertahankan postur kerja dengan keluhan subyektif nyeri leher pada pekerja industri kerajinan kulit di Selosari.

\section{METODE PENELITIAN}

Penelitian ini merupakan penelitian observasional analitik dengan pendekatan cross sectional yang berarti bahwa proses pengumpulan data dilakukan secara serentak pada waktu yang bersamaan (Sugiyono, 2012).

Populasi dan sampel pada penelitian ini adalah pekerja pada industri kerajinan kulit di Selosari sebanyak 47 orang. Sampel pada penelitian ini diambil dengan teknik proportional random sampling yaitu pengambilan sampel secara acak dan proporsional (Sugiyono, 2012). Sampel diambil dari 2 industri dengan jumlah pekerja paling banyak. Jumlah sampel yang diambil dihitung dengan rumus sebagai berikut (Notoatmodjo, 2012):

$$
\begin{aligned}
& n=\frac{N}{1+N d^{2}} \\
& n=\frac{47}{1+47(0,05)^{2}} \\
& n=42
\end{aligned}
$$

Keterangan:

$\mathrm{n}$ : jumlah sampel

$\mathrm{N}$ : jumlah populasi

$\mathrm{d}$ : derajat kepercayaan

sehingga sampel pada penelitian ini sebanyak 42 responden yang diambil secara 
proporsional dan acak, yaitu sebanyak 18 sampel dari industri PS dan 24 sampel dari industri FA.

Data yang diperoleh pada penelitian ini dianalisis dengan analisis univariat untuk mendiskripsikan karakteristik responden berdasarkan usia, jenis kelamin, tingkat pendidikan, serta lama mempertakankan postur kerja dan keluhan subyektif nyeri leher dalam bentuk distribusi frekuensi. Pada penelitian ini, yang dimasud lama mempertahankan postur kerja adalah lamanya waktu/ durasi paparan terhadap faktor risiko yaitu lamanya responden bekerja dalam posisi tubuh tertentu. Lama mempertahankan postur kerja terbagi dalam kategori singkat ( $<1$ jam/hari), sedang (1-2 jam/hari), lama (>2 jam/hari). Sedangkan untuk keluhan subyektif nyeri leher adalah keluhan sakit dan nyeri pada leher yang dirasakan responden, yang dikategorikan nyeri dan tidak nyeri. Keluhan tersebut ditanyakan secara langsung kepada responden dengan instrumen Nordic Body Map (NBM).

Selain itu juga dilakukan analisis bivariat untuk mengetahui hubungan antara variabel bebas (lama mempertahankan postur kerja) dan variabel terikat (keluhan subyektif nyeri leher) dengan hipotesis penelitian yaitu "ada hubungan antara lama mempertahankan postur kerja dengan keluhan subyektif nyeri leher pada pekerja industri kerajinan kulit di Selosari”.

\section{HASIL}

Hasil yang diperoleh pada penelitian ini adalah sebagai berikut:

Tabel 1 Distribusi Frekuensi Jenis Kelamin Responden

\begin{tabular}{lcc}
\hline $\begin{array}{c}\text { Jenis } \\
\text { Kelamin }\end{array}$ & Frekuensi & $\begin{array}{c}\text { Persentase } \\
(\%)\end{array}$ \\
\hline Laki-laki & 34 & 81 \\
\hline Perempuan & 8 & 19 \\
\hline Total & 42 & 100 \\
\hline
\end{tabular}

Berdasarkan tabel 1 dapat dilihat bahwa dari 42 responden, sebagian besar yaitu sebanyak 34 orang $(81 \%)$ berjenis kelamin laki-laki.

Tabel 2 Distribusi Frekuensi Usia Responden

\begin{tabular}{lcc}
\hline Usia & Frekuensi & $\begin{array}{c}\text { Persentase } \\
(\%)\end{array}$ \\
\hline $21-30$ & 15 & 35,7 \\
\hline $31-40$ & 17 & 40,5 \\
\hline $41-50$ & 6 & 14,3 \\
\hline $51-60$ & 4 & 9,5 \\
\hline Total & 42 & 100 \\
\hline
\end{tabular}

Berdasarkan tabel 2 dapat diketahui bahwa sebagian besar responden, yaitu sebanyak 17 orang $(40,5 \%)$ berusia antara 31 - 40 tahun. Sebanyak 4 orang $(9,5 \%)$ berusia 51 - 60 tahun. Dengan usia paling muda 21 tahun dan usia paling tua 58 tahun. 
Tabel 3 Distribusi Frekuensi Tingkat Pendidikan Responden

\begin{tabular}{lcc}
\hline $\begin{array}{c}\text { Tingkat } \\
\text { Pendidikan }\end{array}$ & Frekuensi & $\begin{array}{c}\text { Persentase } \\
(\boldsymbol{\%})\end{array}$ \\
\hline SD & 0 & 0 \\
\hline SMP & 3 & 7,1 \\
\hline SMA/SMK & 36 & 85,8 \\
\hline Diploma/Sarjana & 3 & 7,1 \\
\hline Total & 42 & 100 \\
\hline
\end{tabular}

Berdasarkan tabel 3 dapat dilihat bahwa sebagian besar responden, yaitu sebanyak 36 orang $(85,8 \%)$ berpendidikan SMA/SMK sederajat. Responden yang berpendidikan SMP sebanyak 3 orang $(7,1 \%)$ dan pendidikan Diploma/Sarjana sebanyak 3 orang $(7,1 \%)$.

Tabel 4 Distribusi Lama Responden Mempertahankan Postur Kerja

\begin{tabular}{lcc}
\hline $\begin{array}{c}\text { Lama } \\
\text { Mempertahankan } \\
\text { Postur }\end{array}$ & Frekuensi & $\begin{array}{c}\text { Persentase } \\
(\%)\end{array}$ \\
\hline Singkat & 8 & 19 \\
\hline Sedang & 26 & 62 \\
\hline Lama & 8 & 19 \\
\hline Total & 42 & 100 \\
\hline
\end{tabular}

Berdasarkan tabel 4 dapat diketahui bahwa dari 42 responden, sebagian besar, yaitu sebanyak 26 orang (62\%) mempertahankan postur kerjanya termasuk dalam kategori sedang (1-2 jam/hari). Responden yang dengan lama mempertahankan postur kategori singkat ( $<1$ jam/hari) sebanyak 8 orang $(19 \%)$ dan kategori lama (>2 jam/hari) sebanyak 8 orang (19\%).
Tabel 5 Distribusi Frekuensi Keluhan Subyektif Nyeri Leher Responden

\begin{tabular}{lcc}
\hline $\begin{array}{c}\text { Keluhan } \\
\text { Nyeri Leher }\end{array}$ & Frekuensi & $\begin{array}{c}\text { Persentase } \\
(\mathbf{\%})\end{array}$ \\
\hline Tidak nyeri & 9 & 21,4 \\
\hline Nyeri & 33 & 78,6 \\
\hline Total & 42 & 100 \\
\hline
\end{tabular}

Berdasarkan tabel 5 dapat diketahui bahwa sebagian besar responden, yaitu sebanyak 33 orang $(78,6 \%)$ merasakan keluhan subyektif nyeri pada leher yang terjadi selama atau setelah bekerja. Dan sebanyak 9 orang $(21,4 \%)$ yang tidak merasakan keluhan nyeri leher.

Hasil yang diperoleh selanjutnya analisis dengan uji statistik Chi Square untuk mengetahui hubungan antara lama mempertahankan postur kerja dengan keluhan subyektif nyeri leher.

Tabel 6 Hubungan Antara Lama Mempertahankan Postur Kerja dengan Keluhan Subyektif Nyeri Leher

\begin{tabular}{|c|c|c|c|c|c|}
\hline & & & \multicolumn{2}{|c|}{$\begin{array}{c}\text { Keluhan } \\
\text { nyeri }\end{array}$} & \multirow{2}{*}{ Total } \\
\hline & & & $\begin{array}{l}\text { Tidak } \\
\text { nyeri }\end{array}$ & Nyeri & \\
\hline \multirow{6}{*}{$\begin{array}{l}\text { Lama } \\
\text { postur }\end{array}$} & \multirow{2}{*}{ Singkat } & $\mathrm{f}$ & 6 & 2 & 8 \\
\hline & & $\%$ & 14,2 & 4,8 & 19 \\
\hline & \multirow{2}{*}{ Sedang } & $f$ & 2 & 24 & 26 \\
\hline & & $\%$ & 4,8 & 57,2 & 62 \\
\hline & \multirow{2}{*}{ Lama } & $\mathrm{f}$ & 1 & 7 & 8 \\
\hline & & $\%$ & 2,4 & 16,6 & 19 \\
\hline \multirow{2}{*}{ Total } & & $\mathrm{f}$ & 9 & 33 & 42 \\
\hline & & $\%$ & 21,4 & 78,6 & 100 \\
\hline
\end{tabular}

Berdasarkan tabel 6 dapat diketahui bahwa sebanyak 24 responden $(57,2 \%)$ yang mempertahankan postur kerja kategori sedang merasakan keluhan nyeri 
pada leher. Sebanyak 7 responden $(16,6 \%)$ dengan lama mempertahankan postur kategori lama yang merasakan nyeri leher. Sebanyak 6 responden $(14,2 \%)$ dengan lama mempertahankan postur kategori singkat yang merasakan nyeri leher. Pada responden yang mempertahankan postur kerja kategori singkat sebanyak 2 responden $(4,8 \%)$ dan kategori sedang sebanyak 2 responden $(4,8 \%)$ tidak merasakan keluhan nyeri leher. Serta hanya 1 responden $(2,4 \%)$ dengan lama mempertahankan postur kategori lama yang tidak merasakan keluhan nyeri leher. Hasil uji statistik dengan Chi Square menunjukkan nilai $\mathrm{p}=0,006$; dimana $\mathrm{p}<0,05$ yang berarti bahwa ada hubungan antara lama mempertahankan postur kerja dengan keluhan subyektif nyeri leher pada pekerja industri kerajinan kulit di Selosari.

\section{PEMBAHASAN}

Hasil penelitian menunjukkan bahwa selama melakukan proses pembuatan sepatu dan sandal, postur tubuh responden tidak alamiah yaitu punggung membungkuk dan leher menunduk dan mayoritas responden yaitu sebanyak 26 orang (62\%) mempertahankan postur/ posisi tubuh tersebut dalam jangka waktu/ durasi kategori sedang (1-2 jam/hari). Postur tubuh tidak alamiah terjadi saat bagian tubuh bergerak menjauhi posisi alamiah (Tarwaka, 2015). Termasuk dalam postur tidak alamiah adalah posisi punggung yang terlalu membungkuk, kepala terangkat dan leher yang terlalu menunduk. Yang perlu diperhatikan dari postur kerja tidak alamiah adalah postur statis. Menurut Tarwaka (2015), postur statis merupakan postur saat kerja fisik dalam posisi yang sama dimana pergerakan yang terjadi sangat minim atau gerakan yang dipertahankan > 10 detik.

Lama mempertahankan postur kerja dapat juga diartikan sebagai lamanya waktu/durasi paparan terhadap faktor risiko. Semakin lama durasi paparan akan meningkatkan risiko cidera yang akan terjadi (Octaviani, 2017). Jika pekerjaan berlangsung dalam jangka waktu yang lama, maka kemampuan tubuh akan menurun dan dapat menyebabkan keluhan pada tubuh (Safitri et al, 2017. Dengan demikian, semakin lama responden mempertahankan postur tubuhnya saat bekerja maka akan semakin besar pula risiko munculnya keluhan nyeri leher yang dirasakan.

Berdasarkan keluhan subyektif nyeri leher, hasil penelitian menunjukkan bahwa lebih dari separuh jumlah responden, yaitu sebanyak 33 orang $(78,6 \%)$ merasakan keluhan nyeri leher yang dirasakan baik saat bekerja maupun setelah bekerja. Proses kerja pembuatan sepatu dan sandal yang dilakukan responden dengan postur leher terlalu menunduk yang dilakukan dalam 
jangka waktu relatif lama dan minimnya pergerakan mengakibatkan munculnya keluhan subektif nyeri leher. Menurut Safitri et al (2017), gejala umum terjadinya nyeri leher (neck pain) adalah terasa sakit dan kaku didaerah leher, nyeri otot leher dan sakit kepala. Rasa nyeri tersebut dapat menjalar ke bahu, lengan dan tangan.

Menurut Puspita et al (2017), pekerja bengkel yang melakukan pekerjaan dengan posisi duduk menunjukkan bahwa potur leher memiliki risiko sedang terjadinya keluhan muskuloskeletal. Risiko nyeri leher akan meningkat pada pekerjaan dengan posisi duduk lebih dari $95 \%$ jam kerja atau duduk monoton lebih dari 2 jam dalam sehari. Selain itu, postur tubuh yang salah/ tidak alamiah yang sering menjadi kebiasaan juga dapat meningkatkan risiko munculnya keluhan nyeri leher (Aziza, 2017). Posisi kerja duduk terus-menerus dalam jangka waktu lama mengakibatkan munculnya keluhan berupa pegal-pegal dan nyeri di daerah leher, bahu, tulang belakang, pantat, dan perut (Tarwaka, 2015).

Munculnya keluhan subyektif nyeri leher dapat terjadi karena postur leher terlalu menunduk saat bekerja. Postur tersebut menunjukkan postur yang tidak alamiah, dimana postur tersebut membuat bagian tubuh terutama leher bergerak menjauhi posisi alamiah tubuh/ postur normal. Hasil uji statistik Chi Square menunjukkan nilai $\mathrm{p}=0,006$; dimana $\mathrm{p}<0,05$ yang berarti bahwa ada hubungan antara lama mempertahankan postur kerja dengan keluhan subyektif nyeri leher pada pekerja industri kerajinan kulit di Selosari. Postur kerja statis yang dipertahankan dalam jangka waktu lama dapat meningkatkan risiko munculnya keluhan muskuloskeletal termasuk keluhan nyeri leher (Tarwaka, 2015). Otot akan lebih mudah lelah ketika bekerja dalam postur statis dibandingkan dengan saat bekerja dengan postur dinamis. Postur statis dapat menyebabkan terjadinya nyeri otot leher sehingga dapat juga menurunkan kemampuan fungsional dari leher (Melia et al, 2018). Akan tetapi, hal tersebut bukan menjadi satu-satunya faktor yang berpengaruh terhadap munculnya keluhan nyeri leher. Menurut Tarwaka (2015), faktor-faktor yang berpengaruh terhadap timbulnya keluhan nyeri leher antara lain faktor risiko internal (usia, jenis kelamin, jenis pekerjaan, riwayat penyakit) dan faktor eksternal (aktivitas olahraga, status gizi, masa kerja, lama kerja, lingkungan kerja, postur kerja). Perlu diperhatikan juga bahwa terdapat penyebab kombinasi, dimana risiko timbulnya keluhan nyeri akan semakin meningkat bila dalam melakukan pekerjaannya, pekerja terpapar pada beberapa faktor risiko dalam waktu yang bersamaan. 
Hasil penelitian ini sejalan dengan penelitian Safitri et al (2017) pada pekerja di pabrik sepatu dan sandal kulit Kurnia di kota Semarang yang menunjukkan aktivitas pekerjaan di pabrik sepatu dan sandal kulit Kurnia termasuk aktivitas dengan durasi lama karena dilakukan lebih dari dua jam per hari. Durasi/ lamanya paparan dari faktor risiko tersebut mengakibatkan timbulnya keluhan neck pain. Penelitian ini juga sejalan dengan penelitian Yustica et al (2016) pada penjaga pintu tol Tembalang Semarang dengan hasil yang menunjukkan bahwa ada hubungan antara postur kerja leher dengan tingkat keluhan subyektif muskuloskeletal $(\mathrm{p}=0,009)$ pada penjaga pintu tol Tembalang Semarang. Lengan atas yang terlalu jauh atau terlalu besar sudutnya dari batang tubuh, leher yang terlalu menunduk, tubuh yang terlalu menunduk dapat menjadi faktor penyebab munculnya keluhan muskuloskeletal.

Akan tetapi hasil penelitian ini tidak sejalan dengan penelitian Setyowati et al (2017) pada porter di pelabuhan penyeberangan Ferry Merak Banten yang menunjukkan tidak ada hubungan antara durasi angkat angkut dengan keluhan nyeri leher. Berbeda dengan durasi angkatangkut yang tidak berhubungan dengan keluhan nyeri leher, justru durasi jam kerja menunjukkan ada hubungan dengan keluhan nyeri leher $(p=0,047)$. Secara umum terlihat bahwa semakin lama durasi pajanan/ paparan terhadap faktor risiko, maka akan semakin besar pula tingkat risiko yang terjadi.

Perlu diperhatikan juga bahwa faktor penyebab kombinasi yaitu risiko terjadinya keluhan akan semakin meningkat bila dalam melakukan pekerjaannya, pekerja terpapar pada beberapa faktor risiko dalam waktu yang bersamaan. Lamanya mempertahankan postur leher responden pada posisi terlalu menunduk saat bekerja dan minimnya pergerakan mengakibatkan munculnya keluhan subyektif nyeri leher. Menurut Tarwaka (2015), gangguan pada sistem muskuloskeletal termasuk keluhan nyeri leher, pada umumnya tidak pernah terjadi secara langsung, tetapi lebih merupakan suatu akumulasi dari yang ringan sampai berat secara terus menerus dan dalam jangka waktu yang relatif lama. Responden perlu memperhatikan bahwa lama mempertahan postur leher yang terlalu menunduk saat bekerja yang dilakukan secara terus-menerus dalam jangka waktu lama akan dapat meningkatkan risiko keluhan nyeri leher. Sehingga perlu dilakukan perbaikan terhadap postur tubuh saat bekerja terutama bagian leher maupun pergerakan atau perubahan postur tubuh terutama bagian leher jika mulai terasa pegal atau kaku pada leher.

\section{KESIMPULAN}

Dari hasil penelitian dapat disimpulkan bahwa mayoritas responden 
mempertahankan postur kerjanya dalam kategori sedang yaitu antara 1-2 jam dan sebagian besar responden juga merasakan keluhan subyektif nyeri pada leher baik yang terjadi selama bekerja maupun setelah bekerja. Hasil analisis statistik menunjukkan ada hubungan antara lama mempertahankan postur kerja dengan keluhan subyektif nyeri leher pada pekerja industri kerajinan kulit di Selosari.

\section{SARAN}

Berdasarkan hasil penelitian, maka saran dari peneliti adalah perlu adanya perbaikan postur tubuh responden saat bekerja terutama bagian leher dengan cara tidak terlalu menunduk. Selain hal tersebut, sebaiknya pada saat bekerja lebih sering melakukan perubahan postur tubuh terutama leher untuk menghindari munculnya pegal atau nyeri leher. Serta perlu dilakukan pemeriksaan kesehatan secara berkala untuk menghindari munculnya gangguan kesehatan karena pekerjaan.

\section{DAFTAR PUSTAKA}

Alfara, I., I. Iftadi, dan R.D. Astuti. (2017). Analisis Postur Kerja Operator Perakitan Di Yessy Shoes Untuk Mengidentifikasi Resiko Gangguan Muskuloskeletal Akibat Kerja. Performa. 16(1).

Aziza, N. (2017). Hubungan Antara Faktor Sikap Kerja, Kenyamanan Tempat Duduk Dan Durasi Kerja Dengan Keluhan Nyeri Di Bagian Leher Pada Pekerja Pembuatan Ikan Asin (Studi di Wilayah Muncar-Banyuwangi) (Doctoral dissertation, University of Muhammadiyah Malang).

Ginting, R., \& Malik, A. F. (2016). Analisis

Keluhan Rasa Sakit Yang Dialami Pekerja Pada UKM Sepatu Kulit Di Kota Dengan Menggunakan Kuesioner SNQ. Jurnal Sistem Teknik Industri, 18(1).

Harwanti, S., B. Aji, dan N. Ulfah. (2016). Pengaruh Posisi Kerja Ergonomi Terhadap Low Back Pain (LBP) Pada Pekerja Batik Di Kauman Sokaraja. Kesmasindo. 8(1).

Kudsi, A. F. (2015). Faktor-faktor yang Mempengaruhi Kejadian Nyeri Leher pada Operator Komputer. Jurnal Agromedicine, 2(3).

Melia, D. S., Imania, D. R., \& Fis, M. (2018). Perbedaan Pengaruh Pemberian Static Stretching Exercise Dan Muscle Energy Technique (Met) Terhadap Peningkatan Aktifitas Fungsional Leher Pada Kondisi Neck Pain (Doctoral dissertation, Universitas'Aisyiyah Yogyakarta).

Notoatmodjo S. (2012). Metodologi Penelitian Kesehatan. Rineka Cipta. Jakarta.

Octaviani, D. (2017). Hubungan Postur Kerja Dan Faktor Lain Terhadap Keluhan Muskuloskeletal Disorder's (MSDs) Pada Sopir Bus Antar Provinsi Di Bandar Lampung. Skripsi. Fakultas Kedokteran Universitas Lampung. Bandar Lampung.

Puspita, D., Suroto, S., \& Kurniawan, B. (2017). Analisis Postur Kerja Terhadap Keluhan Musculoskeletal Disorders (Msds) Pada Pekerja Mekanik Bengkel Sepeda Motor X Semarang. Jurnal Kesehatan Masyarakat (e-Journal), 5(5). 
Safitri, A.G., B. Widjasena., B. Kurniawan. (2017). Analisis Penyebab Keluhan Pekerja DI Pabrik Sepatu Dan Sandal Kulit Kurnia Di Kota Semarang. Jurnal Kesehatan Masyarakat (e-Journal). 5(3).

Samara, D. (2007). Nyeri Muskuloskeletal Pada Leher Pekerja Dengan Posisi Pekerjaan Yang Statis. Universa Medicina, 26 (3).

Setyowati, S., Widjasena, B., \& Jayanti, S. (2017). Hubungan Beban Kerja, Postur Dan Durasi Jam Kerja Dengan Keluhan Nyeri Leher Pada Porter Di Pelabuhan Penyeberangan Ferry Merak-Banten. Jurnal Kesehatan Masyarakat (e-Journal), 5(5).

Sugiono. (2012). Statistika Untuk Penelitian. Cetakan ke-20. Alfabeta. Bandung.

Tarwaka. (2015). Ergonomi Industri Dasar-Dasar Pengetahuan Ergonomi dan Aplikasi di Tempat Kerja. Revisi-Edisi II. Cetakan Kedua. Harapan Press. Surakarta.

Yustica, D.D., Suroto, dan Ekawati. (2016). Hubungan Antara Postur Kerja Dengan Tingkat Keluhan Subyektif Muskuloskeletal Pada Penjaga Pintu Tol Tembalang Semarang. Jurnal Kesehatan Masyarakat (e-Journal). 4(3). 